\title{
Schistosomiasis and HIV-1 viral load in HIV- infected outpatients with immunological failure in Tanzania: a case-control study
}

Peter Masikini ${ }^{1}$, Soledad Colombe ${ }^{2^{*}}$ D, Amon Marti ${ }^{1}$, Bernard Desderius ${ }^{1}$, Claudia J. de Dood ${ }^{3}$, Paul L. A. M. Corstjens ${ }^{3}$, Govert J. van Dam ${ }^{4}$, Mwanaisha Seugendo ${ }^{1}$, Samuel Kalluvya ${ }^{1}$ and Jennifer A. Downs ${ }^{1,2}$

\begin{abstract}
Background: Schistosoma sp. infection has been shown to interact with HIV-1 by modifying susceptibility to the virus and impacting AIDS outcome, but very little is known about the potential impact of Schistosoma sp. infection on the efficiency of antiretroviral treatment (ART) in HIV-1 infected individuals. One study suggested increased immunological failure in patients infected with schistosomes compared to those uninfected. To our knowledge, no report exists on the virological response to ART in schistosome-infected individuals. In addition, viral load in HIV-1 infected individuals changes over the course of the HIV infection. This study assessed the impact of HIV-1/ Schistosoma sp. co-infections on viral load in people with immunological failure on ART, taking into account the duration of HIV-1 infection.
\end{abstract}

Methods: We enrolled HIV-1 infected Tanzanian adults over 18 years of age who had used first line ART for more than 6 months and were identified to have immunological failure by the WHO criteria (50\% drop from peak CD4 count, or CD4 count equal to or below baseline after 6 months of ART, or CD4 count below 100cells $/ \mathrm{mm}^{3}$ after 1 year of ART). Patients were also tested for schistosome infection by microscopy for ova in urine and stool and by circulating anodic antigen (CAA) levels in serum. The duration of HIV-1 infection was calculated using baseline CD4+ T-cell (CD4) counts determined at enrollment. Univariable and multivariable analyses were conducted to compare viral loads in schistosome infected and uninfected patients.

Results: A total of 188 patients were enrolled. After univariable analysis, female sex, lower peak CD4 counts, lower current CD4 counts, anemia, and shorter time infected with HIV-1 were all significantly associated with higher viral load. Schistosome infection was not associated with viral load even after adjusting for sex, current CD4 counts and duration of HIV-1 infection.

Conclusions: The current study of HIV-infected patients with immunological failure on ART suggests that once ART is introduced, ART is the dominant driver of viral load and schistosome infection may no longer have an impact.

Keywords: Schistosoma sp. , Circulating anodic antigen, HIV-1, Viral load, Tanzania, ART, Treatment failure

\footnotetext{
* Correspondence: soledad.colombe@gmail.com

${ }^{2}$ Center for Global Health, Department of Medicine, Weill Cornell Medicine,

New York, USA

Full list of author information is available at the end of the article
}

C The Author(s). 2019 Open Access This article is distributed under the terms of the Creative Commons Attribution 4.0 International License (http://creativecommons.org/licenses/by/4.0/), which permits unrestricted use, distribution, and reproduction in any medium, provided you give appropriate credit to the original author(s) and the source, provide a link to the Creative Commons license, and indicate if changes were made. The Creative Commons Public Domain Dedication waiver (http://creativecommons.org/publicdomain/zero/1.0/) applies to the data made available in this article, unless otherwise stated. 


\section{Background}

Schistosoma sp. and HIV are co-endemic globally and an estimated 6 million individuals are co-infected worldwide $[1,2]$. Schistosoma sp. infection has been shown to increase susceptibility to HIV and to impact HIV/AIDS outcomes [3-8]. It has been hypothesized that schistosomeinduced down-regulation of $\mathrm{T}$ helper (Th)-1 immune responses may permit increased viral replication, and that $\mathrm{T}$ regulatory cells may also play an important role in the observed interactions.

Availability of antiretroviral therapy (ART) is increasing, with $61 \%$ of adults infected with HIV being on antiretroviral treatment in sub-Saharan Africa [9]. Yet very little is known about the impact of Schistosoma sp. infection on the effectiveness of ART. One study from Tanzania showed schistosome infection to be significantly associated with immunological failure and poorer CD4+ T-cells (CD4) count gain with ART [10]. However that study did not investigate whether the immunological failure was associated with concomitant increase of viral load (virological failure). Results from human studies of schistosome infection and HIV-1 RNA viral loads are variable, with some showing lower and some showing higher viral replication during schistosome co-infection $[3,11-$ 18].

Our group has recently demonstrated that people with schistosome infections have higher $\mathrm{HIV}-1$ viral load set-points shortly following HIV acquisition, yet that in chronic HIV-schistosome co-infection, viral loads are lower than in those with HIV infection alone [19]. To our knowledge, no report exists on the virological response to ART in schistosome-infected individuals. Furthermore, controlling for duration of HIV-1 infection appears to be a critical factor to consider in studies of HIV-1 and schistosome co-infection, since HIV-1 viral load differs over the course of infection [19, 20].

In the current study, we aimed to assess the impact of HIV-1/Schistosoma sp. co-infections on viral load in HIV-1 infected people with immunological failure on ART, taking into account the duration of HIV-1 infection.

\section{Methods}

\section{Study participants and enrollment}

This study was conducted in HIV outpatient clinics at Bugando Medical Centre (BMC) and Sekou Toure Hospital in Mwanza. The participants were HIV-1 infected adults over 18 years of age, who had used first line ART for more than 6 months and were identified to have immunological failure by the World Health Organization (WHO) criteria. Patients on stavudine-containing regimens were excluded due to this drug's known association with treatment failure [21, 22]. Eligible patients provided urine and stool samples for schistosomiasis testing by microscopy as well as serum for quantitation of schistosome circulating anodic antigen (CAA). Plasma was also collected for viral load measurement. Additional information was extracted from the HIV clinic database and the patient's chart.

\section{Laboratory methods}

Tests for schistosome infections were performed at the National Institute of Medical Research in Mwanza, Tanzania. Microscopic examinations were performed on $10 \mathrm{~mL}$ of urine (for S. haematobium) by the filtration technique and on stool (for S. mansoni) following the Kato Katz method. CAA testing was performed as previously described using a luminescent up-converting phosphor technology in combination with a lateral flowbased platform (UCP-LF) [23, 24]. A $30 \mathrm{pg} / \mathrm{mL}$ cutoff threshold was used. Schistosome infection was defined as having either a positive microscopy or CAA test.

Plasma viral load was quantified using the AmpliPrep/ COBAS $^{\oplus}$ TaqMan $^{\circledast}$ HIV-1 Test (Roche Molecular Systems Inc., Pleasanton, California, USA) machine at the BMC clinical laboratory, with a lower limit of detection of 20 copies/mL. Virological failure was defined as a viral load above 1000 copies/mL.

\section{Statistical analysis}

We estimated that we needed to enroll 190 patients to provide $80 \%$ power to detect the primary outcome, a predicted prevalence of virological treatment failure of $45 \%$ in those with schistosome infection compared to $25 \%$ in those without schistosomes, assuming that $30 \%$ of the study population would be infected with schistosomes [10]. Data was double entered, verified and cleaned using Microsoft Excel 2013 and analysis was performed using STATA version 13. Chi-square tests and t-tests were used to compare presence of demographic and clinical factors in those with versus without schistosome infection. Univariable and multivariable linear regressions were used to determine factors associated with $\log _{10}$ of the viral load, including schistosome infection. All variables significantly associated with the outcome in the univariable analysis were included in the stepwise multivariable analysis. We prespecified that we would include schistosome status and duration of HIV-1 infection in the model.

We calculated the time delay between HIV infection and start of ART using the normal CD4 decay per calendar year in drug naïve individuals as previously described [19], assuming that the upper reference values of CD4 counts in healthy Tanzanians are 1278.9 cells/ $\mu \mathrm{L}$ for men and 1406. 11 cells $/ \mu \mathrm{L}$ for women [25]. In addition, we used the overall CD4 decay per calendar year of 34.5 cells/ $\mu \mathrm{L}$ per year that had been reported from Rakai, Uganda, which has a similar HIV-1 clade composition to Mwanza, Tanzania [26-29]. 
We modeled decay by the square-root function [28], which meant we subtracted 5.87 cells $^{0.5} / \mu \mathrm{L}^{0.5}$ from 35.76 cells $^{0.5} / \mu \mathrm{L}^{0.5}$ for men and 37.51 cells $^{0.5} / \mu \mathrm{L}^{0.5}$ for women per calendar year until the square root of $\mathrm{CD} 4$ count found at time of start of ART was reached. The time period for this to happen was considered to be the estimated period between HIV-1 acquisition and start of ART. The time between start of ART and date of viral load testing was then added to this variable to obtain the total duration of HIV-1 infection. This led to an estimated median time from seroconversion to ART initiation of $4.4[3.11-5.1]$ years, which is similar to what was found using HIV surveillance data [Colombe et al., manuscript in revision].

\section{Definitions}

Immunological failure was defined as either a confirmed $50 \%$ drop from peak CD4 count (if known) during current treatment or as a CD4 count equal to or below baseline after 6-months of ART, or as a CD4 count below 100cells $/ \mathrm{mm} 3$ after 1 year of ART as per WHO guidelines [30]. Poor ART adherence was defined as missing 3 doses on 2 or more days of ART within the last 3 months according to Tanzanian national guidelines [31].

Table 1 Demographic characteristics of 188 HIV-1 outpatients with immunological treatment failure on ART

\begin{tabular}{|c|c|c|c|}
\hline Variable & $\begin{array}{l}\text { Viral load > } 1000 \text { copies } / \mathrm{mL} \\
N(\%) \text { or Median [IQR] } \\
N=79\end{array}$ & $\begin{array}{l}\text { Viral load }<=1000 \text { copies } / \mathrm{mL} \\
N(\%) \text { or Median }[\text { IQR }] \\
N=109\end{array}$ & $p$-value \\
\hline Female & $53 / 79(67.1 \%)$ & $63 / 109(57.8 \%)$ & 0.20 \\
\hline Age in years & $40[34-46]$ & $42[37-48]$ & 0.034 \\
\hline Level of education & & & 0.44 \\
\hline Informal & $47 / 79(59.5 \%)$ & $71 / 109$ (65.1\%) & \\
\hline Any primary schooling & $21 / 79(26.6 \%)$ & 23/109 (21.1\%) & \\
\hline Any secondary schooling & $3 / 79(3.8 \%)$ & $1 / 109(0.9 \%)$ & \\
\hline Any university & $8 / 79(10.1 \%)$ & 14/109 (12.8\%) & \\
\hline Time on ART & & & 0.25 \\
\hline $6 m-1 y$ & $2 / 79(2.5 \%)$ & 1/109 (0.9\%) & \\
\hline $1-2 y$ & $6 / 79(7.6 \%)$ & 18/109 (16.5\%) & \\
\hline $2-3 y$ & 14/79 (17.7\%) & 16/109 (14.7\%) & \\
\hline$>3 y$ & $57 / 79(72.2 \%)$ & 74/109 (67.9\%) & \\
\hline ART Regimen & & & 0.77 \\
\hline AZT/3TC/NVP & $35 / 79(44.3 \%)$ & 49/109 (45.0\%) & \\
\hline $\mathrm{AZT} / 3 \mathrm{TC} / \mathrm{EFV}$ & 10/79 (12.7\%) & 19/109 (17.4\%) & \\
\hline TDF/3TC/EFV & $22 / 79(27.8 \%)$ & 28/109 (25.7\%) & \\
\hline TDF/3TC/EFV & $12 / 79(15.2 \%)$ & 13/109 (11.9\%) & \\
\hline History of change ART Regimen & $34 / 79(43.0 \%)$ & 40/109 (36.7\%) & 0.38 \\
\hline Peak CD4 (cells/ $\mu \mathrm{L})$ & 358 [202-506] & $450[317-630]$ & 0.0027 \\
\hline Current CD4 (cells/ $\mu \mathrm{L})$ & $104[47-179]$ & 192 [125-239] & $<0.001$ \\
\hline History of stopping ART & 19/79 (24.1\%) & 16/109 (14.7\%) & 0.10 \\
\hline Use of herbal/alternative medicine & $32 / 79(40.5 \%)$ & $54 / 109(49.5 \%)$ & 0.22 \\
\hline Other comorbidities & & & 0.38 \\
\hline None & 73/79 (92.4\%) & $94 / 109(86.2 \%)$ & \\
\hline Hypertension & $4 / 79(5.1 \%)$ & $8 / 109(7.3 \%)$ & \\
\hline Others (Diabetes, heart failure, asthma etc.) & $2 / 79(2.5 \%)$ & $7 / 109(6.4 \%)$ & \\
\hline Body mass index in $\mathrm{kg} / \mathrm{m}^{2}$ & $21.5[18.9-25.4]$ & 22 [19.9-24.0] & 0.65 \\
\hline Anemia (Hemoglobin< $12 \mathrm{~g} / \mathrm{dl}$ ) & $50 / 79(6.3 \%)$ & 37/109 (33.9\%) & $<0.001$ \\
\hline Schistosome positivity & $36 / 71(50.7 \%)$ & 49/102 (48.0\%) & 0.73 \\
\hline Ln of CAA $(p g / m l)$ & $3.05[2.1-5.2]$ & $2.8[2.0-6.1]$ & 0.65 \\
\hline Years infected with HIV-1 & $8.9[6.6-11.1]$ & $9.9[7.7-11.4]$ & 0.068 \\
\hline
\end{tabular}


This measure of adherence is routinely recorded at every monthly visit by nurses and doctors at the clinic [31].

\section{Results}

From August to December 2014, we screened 237 outpatients who were diagnosed with immunological treatment failure while using first-line ART. Of these, 31 were using a stavudine-containing regimen, 10 had been on ART for less than 6 months, 6 did not want to participate in the study, and viral load testing failed on 5 patients. Thus we enrolled and analyzed data from a total of 188 patients.

The median age was 41.0 [36.0-46.5] years and 116 (61.7\%) of participants were female. The majority of participants resided in urban areas (152, 80.9\%), were employed and selling food (89, 47. 3\%), and had completed only primary education $(118,62.11 \%) .63 / 87$ $(72 \%)$ of anemic patients were female $(p=0.005) .79 / 188$ (42.0\%) of patients had $>1000$ viral copies $/ \mathrm{mL}$. Among those with viral loads $<1000$ copies $/ \mathrm{mL}$, 94 (86.2\%) were virologically suppressed with viral loads $<20$ copies $/ \mathrm{mL}$.

Table 2 Results of univariable and multivariable analyses of factors associated with $\log _{10}$ of viral load

\begin{tabular}{|c|c|c|c|c|}
\hline \multirow[t]{2}{*}{ Variable } & \multicolumn{2}{|l|}{ Univariable analysis } & \multicolumn{2}{|l|}{ Multivariable analysis } \\
\hline & Slope coefficient [95\%Cl] & $p$-value & Slope coefficient [95\%CI] & $p$-value \\
\hline Female & $0.6[0.07 ; 1.2]$ & 0.029 & $0.6[0.05 ; 1.2]$ & 0.034 \\
\hline Age (as a continuous variable) & $-0.02[-0.05 ; 0.006]$ & 0.11 & & \\
\hline \multicolumn{5}{|l|}{ Level of education } \\
\hline Informal & Ref & & & \\
\hline Any primary schooling & $0.2[-0.5 ; 0.9]$ & 0.56 & & \\
\hline Any secondary schooling & $-0.08[-1.8 ; 1.6]$ & 0.92 & & \\
\hline Any university & $0.03[-0.98 ; 1.04]$ & 0.95 & & \\
\hline \multicolumn{5}{|l|}{ Time on ART } \\
\hline $6 m-1 y$ & Ref & & & \\
\hline $1-2 y$ & $-1.6[-4.0 ; 0.8]$ & 0.20 & & \\
\hline $2-3 y$ & $-1.0[-3.4 ; 1.4]$ & 0.40 & & \\
\hline$>3 y$ & $-0.7[-3.0 ; 1.6]$ & 0.53 & & \\
\hline History of change ART Regimen & $0.2[-0.4 ; 0.8]$ & 0.42 & & \\
\hline \multicolumn{5}{|l|}{ 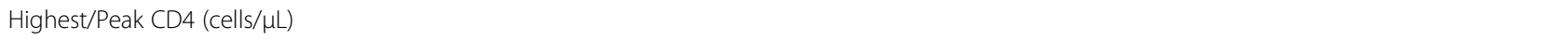 } \\
\hline$<200$ & Ref & & & \\
\hline $200-500$ & $-0.8[-1.6 ;-0.05]$ & 0.037 & & \\
\hline $500-1000$ & $-1.1[-1.9 ;-0.3]$ & 0.011 & & \\
\hline$>1000$ & $-3.0[-6.2 ; 0.2]$ & 0.068 & & \\
\hline \multicolumn{5}{|l|}{ Current CD4 (cells/ $\mu \mathrm{L})$} \\
\hline$<100$ & Ref & & Ref & \\
\hline $100-200$ & $-0.5[-1.2 ; 0.08]$ & 0.090 & $-0.5[-1.1 ; 0.2]$ & 0.15 \\
\hline $200-300$ & $-1.4[-2.2 ;-0.7]$ & $<0.001$ & $-1.3[-2.1 ;-0.5]$ & 0.001 \\
\hline$>300$ & $-2.8[-5.0 ;-0.6]$ & 0.014 & $-3.0[-5.2 ;-0.8]$ & 0.007 \\
\hline History of stopping ART & $-0.05[-0.7 ; 0.6]$ & 0.89 & & \\
\hline Use of herbal/alternative medicine & $-0.1[-0.7 ; 0.4]$ & 0.61 & & \\
\hline \multicolumn{5}{|l|}{ Other comorbidities } \\
\hline None & Ref & & & \\
\hline Hypertension & $-0.7[-1.9 ; 0.6]$ & 0.30 & & \\
\hline Others (Diabetes, heart failure, asthma etc.) & $-0.7[-2.2 ; 0.8]$ & 0.34 & & \\
\hline Anemia & $0.8[0.3-1.4]$ & 0.005 & & \\
\hline Schistosome positivity & $0.15[-0.5 ; 0.8]$ & 0.63 & $0.1[-0.4 ; 0.7]$ & 0.68 \\
\hline Ln of CAA (in $\ln \mathrm{pg} / \mathrm{mL}$ ) & $0.03[-0.04 ; 0.1]$ & 0.42 & & \\
\hline Years infected with HIV-1 & $0.1[0.01 ; 0.2]$ & 0.027 & $0.06[-0.06 ; 0.2]$ & 0.32 \\
\hline
\end{tabular}




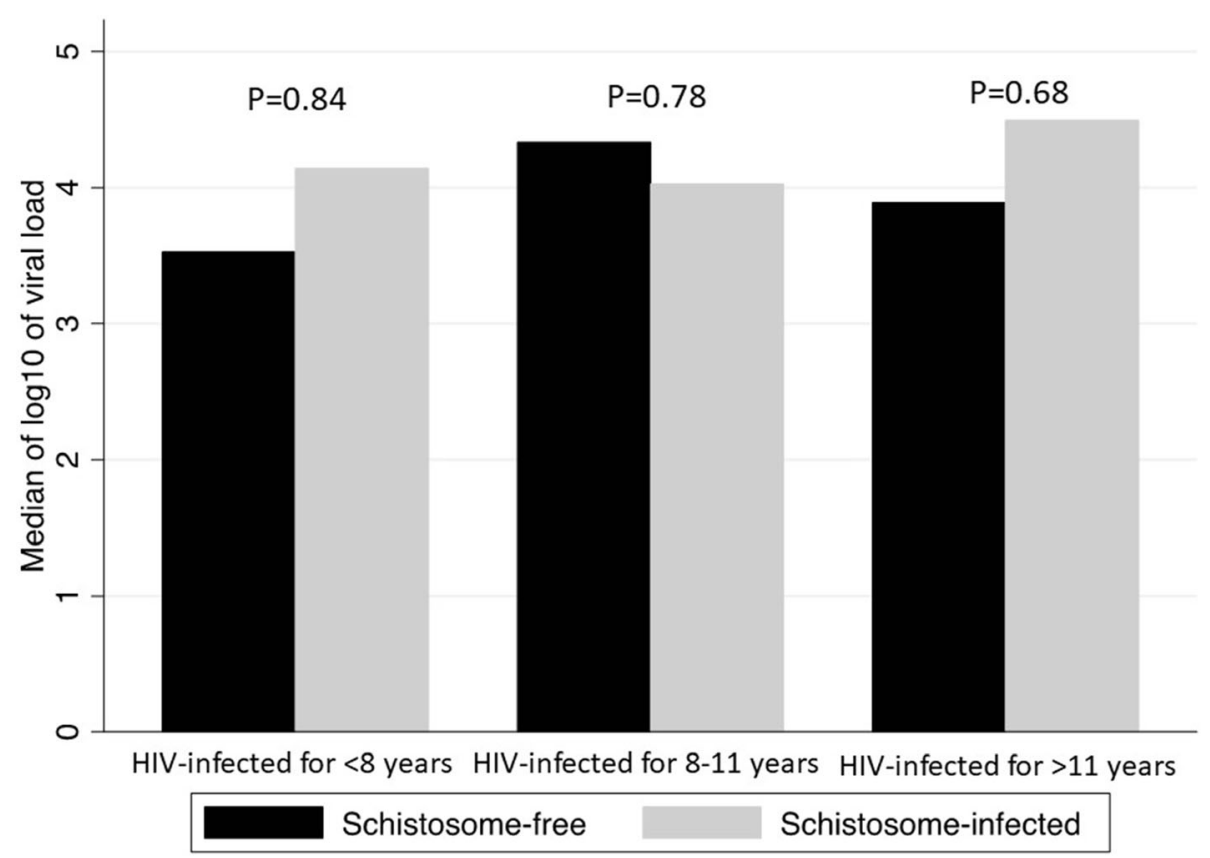

Fig. 1 Difference in $\log _{10}$ of viral load by schistosome status and time infected with HIV-1. Figure shows no difference in median of log 10 of viral load between schistosome infected and uninfected patients with immunological failure on ART across time infected with HIV-1

85/173 (49.1\%) had either a microscopy positive test or a positive CAA test for Schistosoma sp. (Table 1). More specifically, 19/170 (11.18\%) had a stool microscopy positive test, no one had a urine microscopy positive test and $82 / 188(43.62 \%)$ had a positive CAA test. Sixteen people were positive both by CAA and microscopy test.

After univariable analysis, female sex, lower peak CD4 counts, lower current CD4 counts, anemia, and shorter time infected with HIV-1 were all significantly associated with higher $\log _{10}$ of viral load. Schistosome infection was not associated with $\log _{10}$ of viral load.

After multivariable analysis, the best fit model included sex and current CD4 counts. We kept duration of HIV-1 infection in the model. Results of both the univariable and multivariable analyses are presented in Table 2. Neither schistosome infection nor duration of HIV-1 infection was associated with $\log _{10}$ of viral load. The interaction between sex and schistosome status and its impact on $\log _{10}$ of viral load was not statistically significant.

When looking at whether the median $\log _{10}$ of viral load between schistosome infected and non-infected patients changed over time, we found no significant differences (Fig. 1).

\section{Discussion}

We found no association between schistosome infection and viral loads among patients with immunological failure, including after adjustment for time infected with HIV-1. This suggests that observed effects of schistosome infection on HIV-1 viral load occur in the absence of ART and that, once ART commences, effective ART is the dominant driver of viral load. In addition, our finding suggests that the increased immunological failure found by Efraim et al. might be due to an effect of Schistosoma sp. on CD4 counts, but not on viral loads, in people on ART [10].

Our findings, adjusting for duration of HIV-1 infection, differ from those in ART-naïve patients in the same clinic, where schistosome-infection was associated with lower viral loads after adjustment for duration of HIV infection [19]. It is likely that the effect of ART, which typically decreases the viral load by several $\log _{10}$ fold copies $/ \mathrm{mL}$, is so strong that it would mask any effect of schistosome infection on viral load, which we estimated in our prior study to cause a difference of $0.7 \log 10$ copies/mL in ART-naïve patients. Viral load dynamics of patients on ART appear to be vastly different from those of ART naive patients, as suggested by the fact that baseline viral loads do not predict viral load rebounds on ART in previously ART-naïve patients [32].

Expectedly, higher peak and current CD4 counts were associated with lower viral load. This finding is consistent with several other studies in sub-Saharan Africa [33, 34]. Similarly the association between anemia and higher viral load has been shown before [35]. The significant association of female sex with higher viral load as observed in our study contradicted what is usually reported [33, 36, 37]. This might be due to the fact that women were significantly 
more likely to have anemia, which itself is associated with higher viral load and became insignificant when included in the multivariable analysis.

These results need to be considered in light of some limitations. The study included only people with immunological failure, implying that our cohort has overall low CD4 count and thus high viral loads. In addition, as immunological failure is also associated with specific host and viral genetics [38,39], our overall findings may not directly apply to each individual patient on ART. Finally the sample size was calculated for a statistical analysis based on a binary outcome rather than a continuous one. By using viral load as a continuous variable, we lose some power. Nonetheless, the conclusions when using a binary outcome remain the same (Unadjusted Odds Ratio $=1.11[0.61-2.04]$, $p=0.73$; Odds Ratio adjusted for CD4 counts and anemia $=0.99[0.50-1.95], p=0.98$ ).

\section{Conclusions}

In conclusion, our study suggests that schistosome infection does not impact viral load in HIV-1 infected patients immunologically failing on ART, likely due to the major effects of ART on viral load once ART is initiated.

\section{Abbreviations \\ 95\%Cl: 95\% confidence interval; ART: Antiretrovial therapy; BMC: Bugando Medical Centre; CAA: Schistosome circulating anodic antigen; CD4: CD4+ T- cells; IQR: Interquartile range; N: Total number of observations; Th: T-helper; UCP-LF: Luminescent up-converting phosphor technology in combination with a lateral flow-based platform; WHO: World Health Organization}

\section{Acknowledgements}

We would like to thank Theresia Gabriel, Zulkhani Msuya, Shibide Mondea, Leonard Muhoja, Veronica Tungaraza and Revocatus Baraka (Bugando CTC) for helping with data collection. We want to thank Jim Todd (London School of Tropical Hygiene and Medicine) for his input on the calculation of the duration of HIV-1 infection.

\section{Funding}

This work was funded by the Catholic University for Health and Allied Sciences and the Wurzburg Foundation (all funding was awarded to P.M.). The Funding Body had no role in the design of the study and collection, analysis, and interpretation of data nor in writing the manuscript.

\section{Availability of data and materials}

The data that support the findings of this study are available from Revocatus Baraka (revocatusbaraka89@gmail.com) but restrictions apply to the availability of these data, which were used under license for the current study, and so are not publicly available. De-identified data are however available from the authors upon reasonable request and with permission of Revocatus Baraka (revocatusbaraka89@gmail.com).

\section{Authors' contributions}

PM designed the study, collected the data, analyzed the data, interpreted the results and wrote the original manuscript. SC cross-checked and analyzed the de-identified data, interpreted the results and wrote the original manuscript. AM, BD, and MS participated in data collection and contributed in writing the final manuscript. CJdD, PLAMC and GJvD contributed reagents and contributed in writing the final manuscript. SK designed and supervised the study and contributed in writing the final manuscript. JAD performed statistical analysis on the de-identified data set and edited the manuscript. All authors read and approved the final manuscript.

\section{Ethics approval and consent to participate}

All participants were recruited after providing written informed consent. Clearance was obtained from the joint CUHAS/BMC Research Ethics Committee [CREC/037/2014]. All results were made available immediately to clinicians and recorded in the patient's medical record. All patients with schistosome infection received praziquantel $40 \mathrm{mg} / \mathrm{kg}$ in one dose on one single day.

\section{Consent for publication \\ Not applicable.}

\section{Competing interests}

The authors declare that they have no competing interests.

\section{Publisher's Note}

Springer Nature remains neutral with regard to jurisdictional claims in published maps and institutional affiliations.

\section{Author details}

${ }^{1}$ Department of Medicine, Bugando Medical Centre, Mwanza, Tanzania. ${ }^{2}$ Center for Global Health, Department of Medicine, Weill Cornell Medicine, New York, USA. ${ }^{3}$ Department of Cell and Chemical Biology, Leiden University Medical Center, Leiden, Netherlands. ${ }^{4}$ Department of Parasitology, Leiden University Medical Center, Leiden, Netherlands.

Received: 4 September 2018 Accepted: 4 March 2019

Published online: 12 March 2019

\section{References}

1. World Health Organization: Schistosomiasis Fact Sheet. 2018. http:// www.who.int/en/news-room/fact-sheets/detail/schistosomiasis. Accessed 28 May 2018.

2. Mbah MLN, Poolman EM, Drain PK, Coffee MP, van der Werf MJ, Galvani AP HIV and Schistosoma haematobium prevalences correlate in sub-Saharan Africa. Tropical Med Int Health. 2013;18(10):1174-9.

3. Downs JA, Dupnik KM, van Dam GJ, Urassa M, Lutonja P, Kornelis D, et al. Effects of schistosomiasis on susceptibility to HIV-1 infection and HIV-1 viral load at HIV-1 seroconversion: a nested case-control study. PLoS Negl Trop Dis. 2017;11(9):e0005968.

4. Kjetland EF, Ndhlovu PD, Gomo E, Mduluza T, Midzi N, Gwanzura L, et al. Association between genital schistosomiasis and HIV in rural Zimbabwean women. AIDS. 2006;20:593-600.

5. Downs JA, van Dam GJ, Changalucha JM, Corstjens PLAM, Peck RN, de Dood CJ, et al. Association of schistosomiasis and HIV infection in Tanzania. Am J Trop Med Hyg. 2012;87:868-73.

6. Brodish $\mathrm{PH}$, Singh $\mathrm{K}$. Association between schistosoma haematobium exposure and human immunodeficiency virus infection among females in Mozambique. Am J Trop Med Hyg. 2016;94(5):1040-4.

7. Downs JA, de Dood CJ, Dee HE, McGeehan M, Khan H, Marenga A, et al. Schistosomiasis and human immunodeficiency virus in men in Tanzania. Am J Trop Med Hyg. 2017;96(4):856-62.

8. Colombe S, Machemba R, Mtenga B, Lutonja P, Kalluvya SE, de Dood CJ, et al. Impact of schistosome infection on long-term HIV/AIDS outcomes. PLoS Negl Trop Dis. 2018;12(7):e0006613. https://doi.org/10.1371/journal. pntd.0006613.

9. UNAIDS. UNAIDS DATA 2017. 2017. http://www.unaids.org/sites/ default/files/media_asset/20170720_Data_book_2017_en.pdf. Accessed 28 May 2018.

10. Efraim L, Peck RN, Kalluvya SE, Kabangila R, Mazigo HD, Mpondo B, et al. Schistosomiasis and impaired response to antiretroviral therapy among HIV-infected patients in Tanzania. J Acquir Immune Defic Syndr. 2013;62(5):e153-6.

11. Lawn SD, Karanja DM, Mwinzia P, Andove J, Colley DG, Folks TM, et al. The effect of treatment of schistosomiasis on blood plasma HIV-1 RNA concentration in coinfected individuals. AIDS. 2000;14(16):2437-43.

12. Elliott AM, Mawa PA, Joseph S, Namujju PB, Kizza M, Nakiyingi JS, et al. Associations between helminth infection and CD4+ T cell count, viral load and cytokine responses in HIV-1-infected Ugandan adults. Trans R Soc Trop Med Hyg. 2003;97(1):103-8. 
13. Brown M, Kizza M, Watera C, Quigley MA, Rowland S, Hughes P, et al. Helminth infection is not associated with faster progression of HIV disease in coinfected adults in Uganda. J Infect Dis. 2004;190(10):1869-79.

14. Brown M, Mawa PA, Joseph S, Bukusuba J, Watera C, Whitworth JA, et al. Treatment of Schistosoma mansoni infection increases helminth-specific type 2 cytokine responses and HIV-1 loads in coinfected Ugandan adults. J Infect Dis. 2005:191(10):1648-57.

15. Kallestrup P, Zinyama R, Gomo E, Butterworth AE, Mudenge B, van Dam GJ, et al. Schistosomiasis and HIV-1 infection in rural Zimbabwe: effect of treatment of schistosomiasis on CD4 cell count and plasma HIV-1 RNA load. J Infect Dis. 2005;192(11):1956-61.

16. Sangaré $L R$, Herrin BR, John-Stewart G, Walson JL. Species-specific treatment effects of helminth/HIV-1 co-infection: a systematic review and metaanalysis. Parasitology. 2011;138(12):1546-58. https://doi.org/10.1017/ S0031182011000357.

17. Walson J, Singa B, Sangaré L, Naulikha J, Piper B, Richardson B, et al. Empiric deworming to delay HIV disease progression in adults with HIV who are ineligible for initiation of antiretroviral treatment (the HEAT study): a multisite, randomised trial. Lancet Infect Dis. 2012;12(12):925-32.

18. Obuku AE, Asiki G, Abaasa A, Ssonko I, Harari A, van Dam GJ, et al. Effect of Schistosoma mansoni infection on innate and HIV-1-specific T-cell immune responses in HIV-1-infected Ugandan fisher folk. AIDS Res Hum Retrovir. 2016;32(7):668-75. https://doi.org/10.1089/AID.2015.0274.

19. Colombe S, Corstjens PLAM, de Dood CJ, Miyaye M, Magawa RG, Mngara J, et al. HIV-1 viral loads are not elevated in individuals co-infected with Schistosoma spp. after adjustment for duration of HIV-1 infection. Front Immunol. 2018;9:2005.

20. Walson JL, John-Stewart $\mathrm{G}$. Treatment of helminth co-infection in individuals with HIV-1: a systematic review of the literature. PLoS Negl Trop Dis. 2007;1(3):e102.

21. Menezes CN, Maskew M, Sanne I, Crowther NJ, Raal FJ. A longitudinal study of stavudine-associated toxicities in a large cohort of South African HIV infected subjects. BMC Infect Dis. 2011;11:244.

22. van Griensven J, De Naeyer L, Mushi T, Ubarijoro S, Gashumba D, Gazille C, et al. High prevalence of lipoatrophy among patients on stavudinecontaining first-line antiretroviral therapy regimens in Rwanda. Trans R Soc Trop Med Hyg. 2007;101(8):793-8.

23. Corstjens PLAM, De Dood CJ, Kornelis D, Fat EM, Wilson RA, Kariuki TM, et al. Tools for diagnosis, monitoring and screening of Schistosoma infections utilizing lateral-flow based assays and upconverting phosphor labels. Parasitology. 2014;141(14):1841-55. https://doi.org/10.1017/ S0031182014000626

24. van Dam GJ, de Dood CJ, Lewis M, Deelder AM, van Lieshout L, Tanke HJ, et al. A robust dry reagent lateral flow assay for diagnosis of active schistosomiasis by detection of Schistosoma circulating anodic antigen. Exp Parasitol. 2013;135(2):274-82.

25. Ngowi BJ, Mfinanga SG, Bruun JN, Morkve O. Immunohaematological reference values in human immunodeficiency virus-negative adolescent and adults in rural northern Tanzania. BMC Inf Dis. 2009;9:1.

26. Shao ER, Kifaro EG, Kimaro J, Mrema JG, Mwasamwaja AO, Kayandabila J, et al. HIV-1 diversity in Tanzania and its implication toward development of effective vaccines: a review article. J Vaccines Vaccin. 2014;5:249. https://doi. org/10.4172/2157-7560.1000249.

27. Kasang C, Kalluvya S, Majinge C, Stich A, Bodem J, Kongola G, et al. HIV drug resistance (HIVDR) in antiretroviral therapy-naive patients in Tanzania not eligible for WHO threshold HIVDR survey is dramatically high. PLoS One. 2011:6(8):e23091.

28. Kiwanuka N, Robb M, Laeyendecker O, Kigozi G, Wabwire-Mangen F Makumbi FE, et al. HIV-1 viral subtype differences in the rate of CD4+ T-cell decline among HIV seroincident antiretroviral naive persons in Rakai district, Uganda. J Acquir Immune Defic Syndr. 2010;54(2):180-4.

29. Ndembi N, Lyagoba F, Nanteza B, Kushemererwa G, Serwanga J, KatongoleMbidde E. Transmitted antiretroviral drug resistance surveillance among newly HIV type 1-diagnosed women attending an antenatal clinic in Entebbe, Uganda. AIDS Res Hum Retrovir. 2008;24(6):889-95.

30. WHO HIV/AIDS program. Antiretroviral therapy for HIV infection in adults and adolescents. Recommendations for a public health approach. 2010 revision. 2010. http://whqlibdoc.who.int/publications/2010/9789241599764_ eng.pdf?ua=1. Access 28 May 2018.

31. Denison JA, Koole O, Tsui S, Menten J, Torpey K, van Praag E, et al. Incomplete adherence among treatment-experienced adults on antiretroviral therapy in Tanzania, Uganda and Zambia. AIDS. 2015;29(3): 361-71. https://doi.org/10.1097/QAD.0000000000000543.

32. Phillips AN, Staszewski S, Weber R, Kirk O, Francioli P, Miller V, et al. HIV viral load response to antiretroviral therapy according to the baseline CD4 cell count and viral load. JAMA. 2001;286(20):2560-7.

33. Marconi VC, Wu B, Hampton J, Ordóñez CE, Johnson BA, Singh D, et al. Early warning indicators for first-line virologic failure independent of adherence measures in a south African urban clinic. AIDS Patient Care STDs. 2013;27(12):657-68.

34. Evans DH, Maskew $M$, Fox M, McNamara L, MacPhail P, Mathews $C$, et al. CD4 criteria improves the sensitivity of a clinical algorithm developed to identify viral failure in HIV-positive patients on first-line antiretroviral therapy J Int AIDS Soc. 2012;15:122-3.

35. Labhardt ND, Bader J, Ramoeletsi M, Kamele M, Lejone TI, Cheleboi M, et al. Clinical and socio-demographic predictors for virologic failure in rural Southern Africa : preliminary findings from CART-1. J Int AIDS Soc. 2014;17(4 Suppl 3):19666. https://doi.org/10.7448/IAS.17.4.19666.

36. Chalamilla G, Hawkins C, Okuma J, Spiegelman D, Aveika A, Christian B, et al. Mortality and treatment failure among HIV-infected adults in Dar Es Salaam, Tanzania. J Int Assoc Physicians AIDS Care (Chic). 2012;11(5):296-304.

37. Penot $P$, Héma $A$, Bado $G$, Kaboré $F$, Soré $I$, Sombié $D$, et al. The vulnerability of men to virologic failure during antiretroviral therapy in a public routine clinic in Burkina Faso. J Int AIDS Soc. 2014;17:1-7.

38. Easterbrook PJ, Smith M, Mullen J, O'Shea S, Chrystie I, de Ruiter A, et al. Impact of HIV-1 viral subtype on disease progression and response to antiretroviral therapy. J Int AIDS Soc. 2010;13:4. https://doi.org/10.1186/ 1758-2652-13-4.

39. Singh KK, Spector SA. Host genetic determinants of HIV infection and disease progression in children. Pediatr Res. 2009;65(5 Pt 2):55R-63R. https:// doi.org/10.1203/PDR.0b013e31819dca03.

Ready to submit your research? Choose BMC and benefit from

- fast, convenient online submission

- thorough peer review by experienced researchers in your field

- rapid publication on acceptance

- support for research data, including large and complex data types

- gold Open Access which fosters wider collaboration and increased citations

- maximum visibility for your research: over $100 \mathrm{M}$ website views per year

At $\mathrm{BMC}$, research is always in progress.

Learn more biomedcentral.com/submissions 